the moist climate. The groups of natives were always taken as they lived, according to climatic and psychological essentials, the women naked and often painted, the men unembarrassed by more than a loincloth.

\section{THE AMERICAN STATE AND HOUSEHOLD SCIENCE.}

THE application of science to national life and industry in the United States proceeds apace, and affords a very interesting spectacle in its variety of methods and experiments. Undoubtedly great progress is being made amidst a great deal of talk, and America bids fair to rectify itself in relation to science much more quickly than we can do even under the stupendous impact of war and all that it threatens to us. In this process of rectification the United States Government appears to be taking a discreet and effective part. A Bureau of Standards sounds more like Berlin than Washington, but the name is misleading if it suggests bureaucracy and punctilious standardisation. The circulars of the Bureau are, in fact, very careful and admirable scientific publications conveying a vast amount of extremely useful information, usually written in a human way and having behind them nothing in the shape of an act of legislature or compulsory standardisation. The Government gives a lead, it shows you something of which you may avail yourself; you may take it or leave it, but, at any rate, it is there. It is a calamity that we cannot say as much for our own country, where a Board of Trade hardly seems to understand what you mean when you ask it to embody a scientific element.

In one of its latest circulars ${ }^{1}$ the U.S. Bureau of Standards enters upon a new path, attempting to reach the household:- “(I) To give information as to wants, methods, and instruments of measurement useful in household activities; (2) to describe available means of assuring correct quantity in articles bought by weight and measure; and (3) to give other facts of interest which would awaken an appreciation of the rôle of measurement in daily life."

Stress is laid on the educational value of such measurements and on the increase of efficiency in the household, which comes from the habit of thinking in terms of units and definite quantities. The introduction is indeed a temperate and admirable appeal for increased accuracy and better knowledge in the use of household appliances and in the conduct of household operations.

The substance of the circular is comprehensive. It includes chapters on commodities, heat, light, electricity, gas, water, atmospheric humidity, atmospheric pressure, density of liquids, time. In each case the trade and household measuring instruments related to these topics are carefully described both in principle and in mechanical detail, and excellent illustrations abound. There is an abundance also of useful hints directed towards securing efficiency and

1 U.S. Department of Commerce. Circular of the Bureau of Standards No. 55. "Measurements for the Household." NO. 24 I6, VOL. 96] economy, and, in fact, the circular might be called in many respects a treatise on that ambiguous subject known as domestic science.

As such it suffers from a common defect, namely, the attempt to expound scientific principles piecemeal and incidentally, or parenthetically, to single applications. This kind of defect is always visited with severity by the more academic critics, but it may be urged that the defect is not so great as it seems. It is true enough that the contents of this circular, so far as they call for scientific comprehension, will be unassimilable by the ordinary mistress of the household who has only received the one-sided and largely unnegotiable gift of "a good general education." But it is equally true that the anchorage of sound scientific explanations to things and processes of the most obvious practical utility is as likely as anything to direct attention to what has been neglected in one generation and may be secured to another.

Something must be done to demonstrate the place of science in practical affairs, and this seems a legitimate way. Our educational masters seem to make most of their mistakes by forgetting that they are exceptional members of society in having an enthusiasm for abstract knowledge. No doubt the love of knowledge for itself exists to some degree in everyone, and may be developed; but the ordinary circumstances of the world make most people, even at an early age, want to know what use is to be made of knowledge. The fastidious exclusion of the useful from the exposition of the good and true is an unnecessary and fatal extravagance of the pedagogue, and nowhere has its incidence been more lamentable than in the case of natural science. Are we not at the moment bemoaning a nation that does not even know that science is useful? Who or what is responsible for this? Many answers are given, but none is nearer the truth than this: that our teaching has failed. How and where it has failed might be well illustrated by this circular, if those who are engaged in teaching science to the future housewives of England could be examined upon the contents. We should see the reason why such a gap remains between the science of our schools and science in actual use. There is a missing link. It is true of the domestic world, it is true of the industrial world, it is true of the whole national life, and there is urgent need of a remedy. The publication under notice helps to fill one gap, and it should be of real value to those engaged in teaching science to future housewives; and it will help also towards making boys' science more mobile in their homes.

A. S.

\section{THE CLOSING OF MUSEUMS.}

A PROTEST against the closing of museums A (including art galleries) was made to the Prime Minister on February Io by a deputation representing the Museums Association, the National Art Collections Fund, the Royal Asiatic Society, the Hellenic Society, the Art Workers' 
Guild, and the Imperial Arts League. Mr. Asquith, emphasising the need for economy in every direction, explained that the Government had not accepted the recommendation of the Retrenchment Committee in full, since, in addition to the Reading Room of the British Museum, it had decided to keep open the National Gallery and the Victoria and Albert Museum. In view of the numerous colonial visitors and wounded soldiers who resorted to the Natural History Museum, a further concession might be made. "I have," said Mr. Asquith, "come to the conclusion that the portions of the museum which most interest ordinary visitors should remain open, but I do not think that the argument applies to the geological and mineralogical sections. In addition, I hold that facilities should continue to be offered to students at the museum." It was further made plain that the closing had nothing to do with the question of safety; also that the authorities of provincial museums were at liberty to do what they thought best. The galleries and the students' rooms (except that of Manuscripts) at Bloomsbury will be closed on and after March I. As for the Natural History Departments, it remains to be seen which will be closed by the trustees as not interesting ordinary visitors.

We regret that the Prime Minister should have laid stress only on popularity, and should have paid no attention to usefulness. It is not always the most popular exhibits that are the most useful. Galleries left alone by the "ordinary visitor," e.g., that of fossil invertebrates, are much frequented on certain days by collectors and students (not the "students" whom Mr. Asquith had in his mind). But, if popularity is to be the test, surely the Egyptian Department at Bloomsbury and the Fossil Mammal Gallery at South Kensington should not be closed. "Such limitations," said $\mathrm{Mr}$. Asquith, "will last only for a time"; but on what the length of that time is to depend no indication has been given. Our leaders in all branches of intellectual study must be prepared for a struggle lest this action should prove a serious and permanent set-back to research and education, especially in the realms of science.

The following report of the speech made by Sir Ray Lankester as one of the deputation received by the Prime Minister will be of value to those who may be called upon hereafter to discuss this matter.

I am sure that we all agree as to the necessity for retrenchment in public expenditure and sympathise most heartily with the general purpose of the Government in this matter. But we think that the exclusion of the public from the national museums and picture galleries is not well advised, because it will result in a very small saving and a very great public loss. The widespread feeling against this closure has been made evident in the daily Press and by the support given to the present deputation. But I should not wish to urge this as decisive. We fully recognise that the Prime Minister may consider it to be necessary, however reluctantly, to effect this economy; our object is to state facts which seem to us to show that the advantages of such a course are altogether outweighed by the disadvantages. We think that the
Committee on Retrenchment which has reported to the Government in favour of the closure of all public museums and galleries, excepting the reading-room of the British Museum, has not had the facts fully in view.

The great national museums and picture galleries are not mere shows. They, like the great cathedrals which stand always open, are places of rest and mental refreshment in this time of stress and anxiety. They are also a continual source of education and instruction which should not be abandoned even during war, except in case of dire necessity. Were they closed those who now frequent them would seek distraction in less worthy resorts.

It seems to many of us that, in regard to the question of closure of the museums, it is undesirable to make a rule of "all or none." Each case should be judged on its own merits. The saving of expense would be greater in one case than another, and the public disadvantage greater in. one case than another. The Government, we are told, has recognised this, and has decided not to close either the National Gallery or the Victoria and Albert Museum.

I shall therefore confine my remarks to the case of the Natural History Museum, concerning which I have special knowledge, having been for some years its director. The Government does not propose to arrest the work which is done by the curators and other members of the staff in this and other museums. There is no suggestion that the collections should be allowed to deteriorate for want of proper supervision, cleaning, and protection from cold and damp. It is merely proposed to stop the free daily access of the public to the exhibition galleries of the museum. This would tend to a saving at the Natural History Museum of about 20ool. a year, and no more. It would be made by the reduction in the number of police and guardians employed in the public galleries. On the other hand, the building, the glass cases, and the specimens, together with the cost in the past thirty years of arrangement, preparation, and labelling of the exhibited specimens, represent a capital expenditure of not less than a million and a half pounds sterling, which, at 5 per cent., corresponds roughly to an annual sum of $75,000 l$. To this we must add the expenditure of an annual grant, voted by the House of Commons, of $45,000 l$. (reduced from $60,000 l$. to that smaller sum by special economies during the war), giving as the annual cost of the Natural History Museum to the nation a sum of 120,00ol. It is proposed to exclude the public from this great and beautiful show in order to reduce the annual expenditure on it by one-sixtieth. This is recommended by the Retrenchment Committee as "an object-lesson in national economy." It is no doubt necessary to save small sums here and there in many directions of public expenditure. But it. must seem to most people absurd to spend so large a sum on a splendid institution and then, for the sake of a relatively minute reduction of that expenditure, to sacrifice one of the main purposes - if not the main purpose-for which the great expenditure is made-namely, the public edification. It is a maximum of loss and injury to the public with a minimum of financial profit to the National Exchequer.

To obtain a small saving in this way by excluding the public, for whom it exists, from one of its most costly and valued possessions would, moreover, show not only an almost ludicrous misapprehension of the relative proportions of sacrifice and gain, but would be open to the objection that such artion involves a breach of trust on the part of the Trustees, and is contrary to the Act of Parliament under which they exist. The money by which the Natural History No. 24 I6, vol. 96] 
Museum has been built, fitted, and furnished, and that by which it is maintained in full efficiency; has been annually voted by Parliament, and generous benefactors have given priceless collections to it on the express understanding that the museum is-by Act of Parliament-a permanent national possession daily open to the public. It is, of course, understood that the Trustees may close it on certain days for administrative purposes, and in case of national disaster the Government would be justified in suspending all expenditure upon it. But the endeavour to save a minute fraction of the annual cost of the museum by hastilv closing its doors in its owner's face, must lead to public resentment and want of confidence in the Trustees, who alone (and not the Government) are by Act of Parliament distinctly charged with the public duty of keeping it open. As a consequence there might very probably be a resistance in Parliament to the passing of the annual grant by which the museum is maintained, and the good work done there might be curtailed or brought to an end.

It has long been the policy of those who have duly understood the position of the Natural History Museum to give every facility and every assistance to the public in the use and enjoyment of its contents. It was the main care of Sir William Flower when director to make the galleries both delightful and really educative. In that respect $\mathrm{I}$, in my turn, followed him, and recosnised as a fundamental principle of administration that the public must be enabled, in every possible way, to understand and to enjoy the great museum for which it pays. That is no more than a fair and honourable acknowledgment to the taxpayer of the large sums which his Parliamentary representatives (quite independently of the Government of the day) place in the hands of the staff of the museum for the purpose of scientific research and discovery and the maintenance of the museum as a centre of study and expert advice. It is only by securing for it the intelligent interest and appreciation of the public that the Natural History Museum can be assured of the continuance of its annual subsidy. That view, I may say, was one which mas often expressed to me by our late King Edward, when, as Prince of Wales, he was a trustee of the museum. It seems to me that to shut the public out of its museum in order to spare expenditure on the wages of a few superannuated soldiers as watchmen, would be to give public offence without any prospect of compensating advantage, and I therefore venture to hope that the proposal to do so may be reconsidered.

An error, for which we were not responsible, crept into the figures of attendance at the Colchester Corporation Museum, to which we alluded last week. The week-day figures for the last nine months of I9I $_{5}$ were 39,933 . But, even so, the numbers seem to have been quite double those of ordinary years.

\section{NOTES.}

WE announce with deep regret the death on February $\mathrm{I}_{5}$, in his eighty-fifth year, of Sir William Turner, K.C.B., F.R.S., principal and vicc-chancellor of the University of Edinburgh.

WE see with much regret the announcement, in the Times of February in, of the death of Prof. I. P. Pavlov, a foreign member of the Royal Society, late professor of physiology in the University of St. Petersburg, and director of the Imperial Institute for Experimental Medicine.

$$
\text { o. } 24 \text { I6, voL. } 96]
$$

Sir E. Vincent Evans has been appointed chairman of the Royal Commission on Ancient Monuments in Wales and Monmouthshire, in succession to the late Sir John Rhys.

THE death is announced, in his sixtieth year, of Dr. J. O. Reed, who had been connected with the University of Michigan since 1892 , as successively, instructor, assistant professor, and professor of physics. He was the author of a text-book of "College Physics," and, with the late Prof. K. E. Guthe, of a "Manual of Physical Measurements."

According to the British Medical Journal, the foundation-stone of the Hospital for Tropical Diseases of the Calcutta School of Tropical Medicine will be laid on February 24 by Lord Carmichael, the Governor of Bengal. We learn from our contemporary that the whole of the money required for the building has now been collected.

Ar the meeting of the Prehistoric Society of East Anglia on February 7 Mr. J. Reid Moir read a paper on Palæolithic implements found at Darmsden, Suffolk, in a high-level plateau deposit. Some are chopper's or scrapers, while others appear to have been used as borers. All have been made from Lower Eocene pebbles, and appear to represent a hitherto unrecognised type.

AMONG the goods of which the import is prohibited by a Proclamation to come into force on March $\mathrm{I}$, are:-A11 materials for the manufacture of paper, including wood pulp, esparto grass, and linen and cotton rags; paper and cardboard (including strawboard, pasteboard, millboard, and wood pulp board), and manufactures of paper and cardboard; and all periodical publications exceeding 16 pages in length, imported otherwise than in single copies through the post.

The committee of the Privy Council for Scientific and Industrial Research has appointed the Hon. Sir C. A. Parsons, K.C.B., F.R.S., to be a member of the Advisory Council in place of Prof. B. Hopkinson, F.R.S., who has been forced to resign by the pressure of his military duties and special work connected with the war. The committee has also appointed Prof. J. F. Thorpe, F.R.S., to fill the vacancy on the Advisory Council caused by the death of Prof. Raphael Meldola, F.R.S.

According to the Cape Town correspondent of the Times (February II), the Rand has been subject to a series of earth-tremors, which have lately been increasing in frequency and strength. A committee appointed to investigate them has issued a reassuring report. The shocks, it appears, are purely local, being the result of mining operations, and therefore unlikely ever to be of a destructive character. They seem to resemble the earth-shakes which are not uncommon in the mining districts of this country, and are probably due to small movements along faults precipitated by the withdrawal of coal or water.

The Nieuwe Courant of February 3 announces the death, from heart failure, of Dr. August Michaelis, professor of chemistry in the University of Rostock. 